\title{
PENAMBAH AN SAM PAH SAYURAN PADA FERMENTASI BIOGAS DARI KOTORAN SAPI DENGAN STARTER EM4
}

\author{
Sri Widyastuti ${ }^{1)}$ dan Yogi Suyantara ${ }^{1)}$ \\ 1) Program Studi Teknik Lingkungan; Fakultas Teknik Sipil dan Perencanaan \\ Universitas PGRI Adi Buana Surabaya \\ Email: rafirudi@yahoo.co.id
}

\begin{abstract}
Abstrak
Jumlah sampah sayuran yang dihasilkan dari kegiatan pasar sangat melimpah, sampah sayuran dimanfaatkan sebagai bahan pembuatan pupuk kompos, selain digunakan sebagai bahan baku pupuk sampah sayuran dapat juga dimanfaatkan menjadi biogas. Tujuan dari penelitian ini untuk mengetahui pengaruh penambahan komposisi sampah sayuran pada fermentasi biogas dari kotoran sapi. Reaktor berupa digester drum kapasitas 150 liter sampah sayuran dicampur dengan kotoran sapi dan ditambah Effektive Microorganisme (EM4). Proses fermentasi selama 20 hari. Penelitian ini menggunakan 3 variasi berat sampah sayuran yaitu berat sampah sayuran $10 \mathrm{~kg}, 14 \mathrm{~kg}$, dan $18 \mathrm{~kg}$. Hasil penelitian menunjukkan dengan semakin banyaknya takaran sampah sayuran maka tekanan gas yang dihasilkan semakin besar, tetapi berbanding terbalik dengan uji nyala api. Nilai uji tekanan gas dan uji lama nyala api pada sampel P1,P2, dan P3 berturut-turut 27,73 cm., 78 detik, 20,67 cm., 38,06 detik, dan 27,83 cm., 23,23 detik.
\end{abstract}

Kata kunci : Sampah Sayuran, Fermentasi, Biogas, Pupuk Organik.

\begin{abstract}
The amount of garbage generated from activities vegetable market is very abundant, trash vegetables used as materials composting, besides being used as a fertilizer raw materials can also be utilized vegetable trash into biogas. The purpose of this study to determine the effect of vegetable waste composition in fermentation biogas from cow manure. Reactor with a capacity of 150 litre drum digester. Materals such as vegetable garbage mixed with cow dung and Effective Microorganisme (EM4) and fermented for $20^{\text {th }}$ day. This study is experiments with 3 weight variation vegetables bins namely vegetable waste weight $10 \mathrm{~kg}, 14 \mathrm{~kg}$, and $18 \mathrm{~kg}$. The result showed a growing number of doses of the vegetable garbage generated gas pressure getting bigger, but inversely with old flame test. Rated gas pressure test and a long test on the sample flame $P 1, P 2$, dan $P 3$ respectively $27,73 \mathrm{~cm}$., 78 second, 20,67 cm., 38,06 second, and 27,83 cm., 23,23 second.
\end{abstract}

Keywords : Trash Vegetables, Fermentation, Biogas, Organic fertilizer. 


\section{PENDAHULUAN}

Jumlah peningkatan timbulan sampah di Indonesia telah mencapai 175.000 ton/hari atau setara 64 juta ton/tahun (http://www. menlh.go.id/). Namun di sisi lain penanganannya masih belum optimal. Terutama sampah yang ada di pasar.

Pasar sebagai salah satu penopang perekonomian suatu negara juga sebagai penyumbang sampah sayuran terbesar. Sampah sayuran yang cukup melimpah dari kegiatan pasar banyak diolah menjadi kompos, tetapi baru sebagian kecil memanfaatkan sampah sayuran menjadi bahan pembuatan biogas, oleh karena untuk itu perlu dilakukan penelitian pembuatan biogas dengan sampah sayuran sebagai bahan tambahan.

Keuntungan pembuatan biogas dari sampah kota yaitu tidak perlu penambahan nutrien, karena jumlah $\mathrm{N}$ dan $\mathrm{P}$ pada sampah kota yang dalam penelitian ini berupa sampah sayur sangat besar (Oemar.G.R, dkk, 2007).

Sampah sayuran pasar dalam penelitian ini meliputi berbagai jenis sayuran yang umum, misalnya: kubis, kangkung, bayam, tomat, timun, sawi, dan sebagainya, sampah sayuran mengandung lebih banyak bahan organik yang mudah membusuk, lembab, dan mengandung sedikit cairan, dan dapat terdekomposisi secara cepat, terutama ketika cuaca hangat. Sampah sayuran sebagai substrat bagi mikroorganisme dalam proses fermentasi.

Tujuan dari penelitian ini untuk mengetahui pengaruh penambahan sampah sayuran pada proses fermentasi biogas yang berasal dari kotoran sapi..

Variabel yang diuji adalah tekanan gas dengan menggunakan manometer dan uji lama nyala api dengan membakar gas yang dihasilkan, serta pemeriksaan kualitas pupuk organik yang dihasilkan. Apakah pupuk organik hasil dari proses fermentasi biogas telah memenuhi Peraturan Menteri Pertanian Nomor 70/Permentan /SR.140 /10/2011.

Biogas merupakan sebuah proses produksi gas bio dari material organik dengan bantuan bakteri. Proses degradasi material organik ini tanpa melibatkan oksigen (an-aerobic digestion).

Biogas dihasilkan dari proses fermentasi bahan-bahan organik yang dibantu oleh bakteri anaerob di lingkungan tanpa oksigen bebas, biogas didominasi oleh gas metan (55\% - 75\%), karbondioksida (25\% $45 \%$ ), dan beberapa gas lain dalam jumlah yang lebih kecil. Biogas dihasilkan dari proses fermentasi bahan-bahan organik yang dibantu oleh bakteri anaerob di lingkungan tanpa oksigen bebas, biogas didominasi oleh gas metan (55\% - 75\%), karbondioksida $(25 \%-45 \%)$, dan beberapa gas lain dalam jumlah yang lebih kecil.

Tabel 1. Komposisi Biogas

\begin{tabular}{ll}
\hline \multicolumn{1}{c}{ Komponen } & \multicolumn{1}{c}{$\begin{array}{c}\text { Persentase } \\
(\boldsymbol{\%} \text { Volume })\end{array}$} \\
\hline Metana (CH4) & $55-75$ \\
Karbon dioksida (CO2) & $25-45$ \\
Nitrogen (N2) & $0-0.3$ \\
Hidrogen (H2) & $1-5$ \\
Hidrogen sulfida (H2S) & $0-3$ \\
Oksigen (O2) & $0,1-0,5$ \\
\hline Surige $: \mathrm{H}$
\end{tabular}

Sumber : Hermawan. B, dkk. 2007

Proses pembuatan biogas di pengaruhi oleh beberapa faktor, diantaranya adalah suhu, $\mathrm{pH}$, substrat, pengadukan dan starter. Suhu optimum bakteri metanogenik yang bersifat mesofilik adalah $35^{\circ} \mathrm{C}$, bakteri metanogenik termofilik adalah $50{ }^{\circ}-60^{\circ} \mathrm{C}$ (Gerardi, 2003). pH pembentukan gas metan berkisar antara 5,5-8,5, dengan interval optimalnya adalah 7,0-8,0 untuk kebanyakan bakteri metanogen (Seadi et al, 2008). Tahap pertama material orgranik akan didegradasi menjadi asam asam lemah dengan bantuan bakteri pembentuk asam. Bakteri ini akan menguraikan sampah pada tingkat hidrolisis dan asidifikasi. Hidrolisis yaitu penguraian senyawa kompleks atau senyawa rantai panjang seperti lemak, protein, karbohidrat menjadi senyawa yang sederhana. Sedangkan asidifikasi yaitu pembentukan asam dari senyawa sederhana (Pambudi, 2008) dalam (Mujahidah et al., 2013). Beberapa kondisi optimum proses produksi biogas disajikan dalam Tabel 2 berikut.

Tabel 2. Parameter Pengolahan Limbah Organik Menjadi Biogas

\begin{tabular}{lc}
\hline \multicolumn{1}{c}{ Parameter } & Kondisi Optimum \\
\hline Suhu & 35 Derajat C \\
Derajat Keasaman & 7,72 \\
Nutrien Utama & Karbon dan Nitrogen \\
Nisbah Karbon dan Nitrogen & $20 / 1$ sampai 30/1 \\
Sulfida & $<200 \mathrm{mg} / \mathrm{l}$
\end{tabular}




$\begin{array}{lc}\text { Logam - logam Berat terlarut } & <1 \mathrm{mg} / \mathrm{l} \\ \text { Sodium } & <5000 \mathrm{mg} / \mathrm{l} \\ \text { Kalsium } & <2000 \mathrm{mg} / 1 \\ \text { Magnesium } & <1200 \mathrm{mg} / \mathrm{l} \\ \text { Amonia } & <1700 \mathrm{mg} / \mathrm{l}\end{array}$

Sumber: www.unsoed.ac.id (2004)

Pembuatan biogas dilakukan dengan mencampurkan kotoran sapi pada sampah organik yang dimasukkan kedalam digester yang anaerob. Dalam waktu tertentu biogas sudah terbentuk dan dapat digunakan sebagai sumber energi, misalnya untuk kompor, pembangkit listrik dll (Sutrisno, 2010).

Pemanfaatan kotoran sebagai substrat biogas juga dapat menghasilkan pupuk organik untuk tanaman. Biogas yang telah melalui proses fermentasi akan menghasilkan lumpur, lumpur tersebut nantinya dapat dijadikan sebagai pupuk cair ataupun pupuk kompos. Untuk membuat pupuk cair dari lumpur tersebut disaring hasilnya telah menjadi pupuk sedangkan yang padatan dapat dijadikan sebagai pupuk kompos, selanjutnya ditambahkan senyawa untuk tercapai komposisi yang diinginkan misalnya Nitrogen (N), Phospor (P), Kalium (K), Magnesium (Mg), Kalsium (Ca)

\section{METODE}

\section{A. Alat dan bahan}

Alat

a. Peralatan untuk membuat Reaktor Drum plastik 150 liter, Pipa PVC 3/4 dim, Kran air 3/4 dim, Silotip, Karet ban, dan Lem castol.

b. Peralatan untuk membuat manometer

c. Peralatan untuk membuat kompor biogas sebagai pengukur lama nyala api

d. Slang air ukuran $3 / 4$ dim, Pipa besi ukuran $1 / 2$ dim, dan Alat ukur waktu stopwatch.

e. Peralatan pengambilan sampel pupuk

f. Botol sirup dari kaca, Panci plastik, Saringan, Plastik es batu ukuran $1 / 2 \mathrm{~kg}$.

Bahan

a. Sampah sayuran dari Pasar Kedungrejo Kec. Waru Kab. Sidoarjo.

b. Kotoran sapi dari Rumah Potong Hewan Prambon Sidoarjo.

c. EM4 Pertanian.

d. Air dengan perbandingan 1:1 dengan bahan.

\section{b. Proses Pembuatan Biogas}

1. Sampel limbah sayuran $10 \mathrm{~kg}, 14$ $\mathrm{kg}$, dan $18 \mathrm{~kg}$ di cacah, ditambah kotoran sapi dimasukkan digester ditambah air dengan perbandingan 1 : 1, ditam -bahkan EM 4 Pertanian, selanjutnya dilakukan proses fermentasi.

2. Setiap hari di lihat tekanan yang terjadi

3. Hari ke 20 di lakukan uji nyala

Setelah sludge terbentuk, dilakukan pengambilan sludge yang merupakan pupuk organik yang terbentuk kemudian dianalisis kandungan $\mathrm{C}, \mathrm{N}, \mathrm{C} / \mathrm{N}$ rasio dan bakteri salmonella.Pengujian dilakukan di Labora-torium POLTE-KKES KEMENKES Surabaya.

Kondisi operasi kegiatan ini dilakukan secara batch dalam skala laboratorium pada tekanan dan temperatur ruang dari setiap perlakuan variasi percobaan .

\section{HASIL DAN PEMBAHASAN}

1. Data hasil uji tekanan gas dapat dilihat pada Gambar 2.

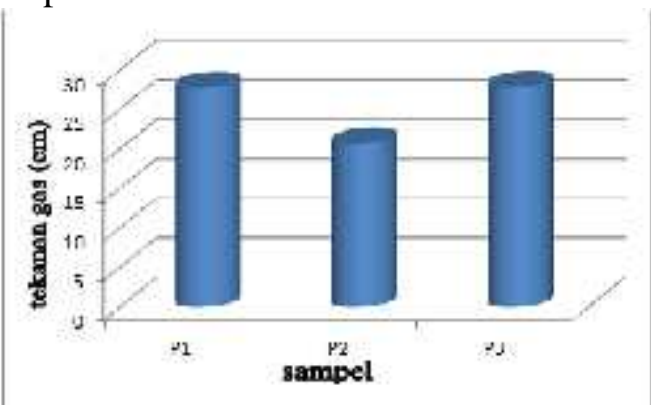

Gambar 2. Diagram Uji Tekanan Gas

Dari Gambar 2 dapat dilihat bahwa tekanan gas tertinggi dicapai pada sampel P3 dengan berat sampah sayuran $18 \mathrm{~kg}$ sebesar $27,83 \mathrm{~cm}$, Peningkatan produksi gas ini terjadi dikarenakan beberapa faktor yaitu (1) volume bahan yang lebih banyak dari variasi yang lain, ini menunjukkan bahwa dengan semakin banyaknya sampah organik akan mempengaruhi tekanan gas yang lebih besar, (2) perbedaan elastisitas antar reaktor biogas yang pada penelitian ini menggunakan reaktor 3 buah dari drum plastik yang apabila terkena suhu yang cukup tinggi atau panas dapat mengembang sehingga dapat mempengaruhi perbedaan tekanan. 
Biogas juga mengandung uap air yang jumlahnya tergantung pada suhu udara. Apabila suhu udara naik kandungan uap air didalam biogas akan meningkat, begitu pula sebaliknya, sampah organik mengandung banyak kadar air sehingga akan meningkatkan penguapan jika pada saat suhu sedang panas (Yunus, 1991). Menurut Schluter et al., (2008) dalam Linda Wati et al., (2014). Komponen biogas terdiri atas 50-70\% metan, 30$40 \%$ karbondioksida, dan sebagian kecil gas lainnya seperti nitrogen, hidrogen dan oksigen.

2. Hasil uji lama nyala api

Data hasil uji lama nyala api diambil dengan 3 kali ulangan atau percobaan dan selanjutnya diambil rata- rata, hasil rata- rata dapat dilihat pada Gambar 3.

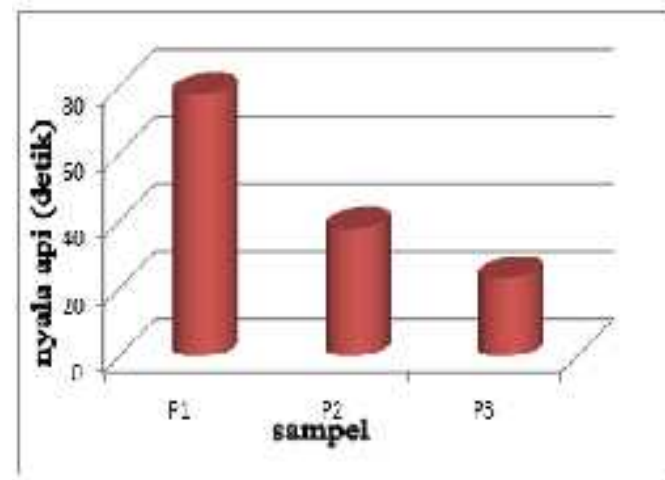

Gambar 3. Diagram Uji Lama Nyala Api

Dari Gambar 3 dapat dilihat bahwa lama nyala tertinggi dicapai pada sampel nomor 1 atau P1 selama 78 detik, dan mengalami penurunan pada sampel nomor 2 atau P2 selama 38,06 detik, dan mengalami penurunan kembali pada sampel nomor 3 atau P3 selama 23,23 detik. Semakin tinggi kandungan metana maka semakin besar kandungan energi (nilai kalor) pada biogas, dan sebaliknya semakin kecil kandungan metana semakin kecil nilai kalor. Kualitas biogas dapat ditingkatkan dengan memperlakukan beberapa parameter yaitu : Menghilangkan hidrogen sulphur, kandungan air dan karbon dioksida $\left(\mathrm{CO}_{2}\right)$. Hidrogen sulphur mengandung racun dan zat yang menyebabkan korosi, bila biogas mengandung senyawa ini maka akan menyebabkan gas yang berbahaya sehingga konsentrasi yang di ijinkan maksimal 5 ppm.
3. Perbandingan hasil uji tekanan gas dan uji lama nyala api di sajikan dalam dalam Tabel 3.

Tabel 3. Data Rata- Rata Tekanan Gas Dan Lama Nyala Api

\begin{tabular}{cccl}
\hline Percobaan & $\begin{array}{c}\text { Berat } \\
\text { Sayur }\end{array}$ & $\begin{array}{c}\text { Rata- } \\
\text { rata } \\
\text { Tekanan }\end{array}$ & $\begin{array}{c}\text { Rata-rata } \\
\text { Nyala Api }\end{array}$ \\
\hline 1 & $10 \mathrm{~kg}$ & 27,73 & 78 detik \\
2 & $14 \mathrm{~kg}$ & 20,67 & 38,06 detik \\
3 & $18 \mathrm{~kg}$ & 27,83 & 23,23 detik \\
\hline
\end{tabular}

Dari Tabel 3. Dapat dilihat bahwa semakin banyak komposisi sampah sayuran maka tekanan gas juga semakin tinggi, pada hasil uji lama nyala api jika komposisi sampah sayuran semakin banyak maka lama nyala api semakin sedikit.

Biogas mengandung uap air yang jumlahnya tergantung pada suhu udara. Apabila suhu udara naik kandungan uap air didalam biogas akan meningkat, begitu pula sebaliknya. Selain mengandung uap air, biogas juga mengandung hydrogen sulfide $\left(\mathrm{H}_{2} \mathrm{~S}\right)$ dan karbondioksida $\left(\mathrm{CO}_{2}\right)$. Gas $\mathrm{H}_{2} \mathrm{~S}$ yang besarnya tidak lebih dari 2 persen berasal dari pemecahan bahan organik substrat oleh mikroba. Gas $\mathrm{CO}_{2}$ dapat mengganggu dalam proses pembakaran atau mengurangi daya bakar per satuan volume, sehingga perlu dihilangkan agar dapat meningkatkan nilai bakar biogas (Yunus, 1991).

4. Hasil pemeriksaan parameter pupuk organik dari lumpur biogas.

Suatu bahan untuk dapat terdistribusi dengan air tergantung pada ukuran partikel suatu bahan. Ukuran partikel yang kecil sangat mendukung dalam proses pelarutan bahan-bahan organik guna menguraikan zat organik tersebut menjadi asam organik yang kemudian dikonversi menjadi $\mathrm{CH} 4$ dan $\mathrm{CO} 2$.

Proses fermentasi anaerobik berlangsung melalui tahap-tahap proses hydrolysis, acidogenesis, acetogenesis, dan methanogenesis, sehingga menghasilkan biogas dan terus bertambah setiap hari selama bakteri pengurai masih terus bertumbuh dan beraktivitas.

Pada hari ke-0 adalah hari pengisian umpan bersama kotoran sapi. Pada hari 
pertama akan terjadi perubahan atau penurunan $\mathrm{pH}$ secara drastis. Hal ini menunjukkan bahwa proses fermentasi anaerobik sedang berlangsung. Dimulai dari tahap proses hydrolysis, dimana terjadi dekomposisi senyawa organik makromolekul seperti protein, karbohidrat, dan lemak menjadi monomer yang mudah larut seperti glukosa, asam lemak, dan asam amino yang dilakukan oleh lipolytic bacteria, cellulolytic bacteria, dan proteolytic bacteria.

Proses acidogenesis, dimana monomer organik diuraikan lebih lanjut oleh acidogenic bacteria menjadi asam -asam organik seperti asam format, asetat, butirat, propionat, laktat, amonia, serta dihasilkan juga $\mathrm{CO} 2, \mathrm{H} 2$, dan etanol. Acidogenic bacteria ini memerlukan $\mathrm{pH}$ berkisar 4,5 7. Proses acetogenesis, pada proses ini senyawa asam organik dan etanol diuraikan acetogenic bacteria menjadi asam format, asetat, $\mathrm{CO} 2$, dan $\mathrm{H} 2$

Proses methanogenesis, yaitu perubahan dari asam asetat menjadi $\mathrm{CH} 4$, $\mathrm{CO} 2, \mathrm{HO} 2$. Methanogenic bacteria bekerja pada kisaran $\mathrm{pH} 6,2$ - 7,8. Namun pada percobaan ini methanogenic bacteria ekerja optimum sampai pada $\mathrm{pH}$ 7,02 untuk komposisi sampah organik padat-cair, $\mathrm{pH}$ 7,15 untuk komposisi sampah organik padat dan $\mathrm{pH}$ 7,03 untuk komposisi sampah organik cair. Pada hari ke-23 (sampah organik padat) dan hari ke-24 (sampah organik padat-cair dan sampah organik cair) terjadi penurunan $\mathrm{pH}$ untuk semua komposisi sampah organik

Bakteri Methanogenic bekerja optimum sampai pada pH 7,02 untuk komposisi sampah organik padat-cair, $\mathrm{pH}$ 7,15 untuk komposisi sampah organik padat dan $\mathrm{pH}$ 7,03 untuk komposisi sampah organik cair. Pada hari ke-23 (sampah organik padat) dan hari ke-24 (sampah organik padat-cair dan sampah organik cair) terjadi penurunan $\mathrm{pH}$ untuk semua komposisi sampah organik. Hal ini disebabkan karena pada proses hydrolysis terjadi dekomposisi protein menjadi ammonium. Ammonium berkesetimbangan dengan NH3 dari larutan dan hasil biogas.Ammonium pada konsentrasi tinggi dapat bersifat racun dan menginhibisi proses anaerobik. (David Bahrin, Destilia Anggraini, Mutiara Bunga Pertiwi,2011)

Pada hasil pemeriksaan parameter sludge (pupuk organic) yang memenuhi SNI adalah pada semua sampel sludge (pupuk organic) cair yang di autoclave dengan parameter $\mathrm{N}$, Rasio $\mathrm{C} / \mathrm{N}$ dan angka kuman salmonella $s p$, pada parameter angka kuman salmonella $s p$ memenuhi SNI peraturan Menteri Pertanian Nomor 70/Permentan /SR.140/10/2011 dikarenakan pada sampel ini dilakukan sterilisasi, dimana dapat membunuh renik yang paling tahan panas yaitu spora bakteri (Fardiaz, 1992).

Tabel 4. Rekapitulasi Data Pemeriksaan C, N, Rasio C/N, Dan Sallmonella Sp

\begin{tabular}{clcccc}
\hline \multirow{2}{*}{ Sampel } & \multicolumn{1}{c}{ Jenis sludge } & $\begin{array}{c}\text { Angka kuman } \\
\text { Salmonella } \\
\text { (CFU/ml) }\end{array}$ & \% N & \% C & $\begin{array}{c}\text { C/N } \\
\text { rasio }\end{array}$ \\
\hline \multirow{2}{*}{1} & Cair di autoclave & $0,5 \times 10^{2}$ & 3,66 & 5,06 & 16,36 \\
& Cair tanpa di autoclave & $3,2 \times 10^{4}$ & 2,27 & 3,18 & 7,40 \\
& Padat & $3,8 \times 10^{4}$ & 2,19 & 2,93 & 7,17 \\
& Cair di autoclave & $0,7 \times 10^{2}$ & 3,63 & 5,09 & 16,31 \\
& Cair tanpa di autoclave & $3,5 \times 10^{4}$ & 2,29 & 3,21 & 7,45 \\
3 & Padat & $4,1 \times 10^{4}$ & 2,21 & 3,01 & 7,20 \\
& Cair di autoclave & $0,3 \times 10^{2}$ & 3,59 & 5,11 & 16,28 \\
& Cair tanpa di autoclave & $3,6 \times 10^{4}$ & 2,31 & 3,22 & 7,43 \\
& Padat & $3,5 \times 10^{4}$ & 2,23 & 2,98 & 7,26 \\
\hline
\end{tabular}

Pada Tabel 4. terlihat bahwa biogas yang dihasilkan tiap bahan memiliki volume yang berbeda-beda. Produksi biogas dari sampah organik padat berjalan lebih lambat daripada sampah organik padat-cair dan sampah organik cair. Namun pada akhirnya produksi biogas dari sampah organik padat dapat menyusul dan menghasilkan biogas terbanyak daripada sampah organik padatcair dan sampah organik cair.

Substrat yang menjadi bahan pembuatan biogas memiliki kandungan $\mathrm{C} / \mathrm{N}$ yang berbeda-beda. Bakteri mengkonsumsi habis unsur $\mathrm{C}$ tiga puluh kali lebih cepat 
dibandingkan unsur $\mathrm{N}$, sedangkan unsur karbon digunakan sebagai sumber energi dan unsur nitrogen di gunakan sebagai pembangun struktur sel bakteri (Bayuseno, 2009).

\section{KESIMPULAN}

Berdasarkan hasil penelitian yang telah dilaksanakan, mengacu pada hasil gas dan uji nyala dapat ditarik kesimpulan bahwa:

1. Tekanan gas optimum pada fermentasi hari ke 20 dicapai pada sampel P3 sampah sayuran $18 \mathrm{~kg}$ sebesar $27,83 \mathrm{~cm}$ dan untuk uji lama nyala api optimum dicapai pada sampel P1 sampah sayuran $10 \mathrm{~kg}$ sebesar 78 detik.

2. Pada hasil uji pemeriksaan laboratorium yang memenuhi SNI peraturan Menteri Pertanian Nomor 70/ Permentan /SR.140/10/2011 adalah sampel sludge (pupuk cair organic) yang diautoclave dengan parameter angka kuman salmonella sp, kadar N, dan Rasio C/N.

\section{Ucapan Terima Kasih}

Ucapan terima kasih ditujukan kepada Universitas PGRI Adi Buana (UNIPA) Surabaya yang telah mendukung penelitian dan memberikan fasilitas laboratorium.

\section{DAFTAR PUSTAKA}

Bayuseno, A., P. 2009. Penerapan Dan Pengujian Model Teknologi Anaerob Digester Untuk Pengolahan Sampah Buah-Buahan Dari Pasar Tradisional. Jurnal Rotasi. Vol: 11 (II). Hal.5.

David Bahrin, Destilia Anggraini, Mutiara Bunga Pertiwi. 2011. Pengaruh Jenis Sampah, Komposisi Masukan dan Waktu Tinggal Terhadap Komposisi Biogas Dari Sampah Organik Pasar Di Kota Palembang, Prosiding Seminar Nasional AVoER ke-3 Palembang, 26-27 Oktober 2011, ISBN : 979-587-395-4

Fardias, S. 1992. Mikrobiologi Pangan, Gramedia Pustaka Utama, Jakarta. Diakses pada tanggal 20 Juli 2016.

Gerardi, M. H. 2003. The Microbiology of Anaerobic Digester. Canada: John Wiley and Sons, Inc

Hardjo, S., N. S. Indrasti dan T. Bantacut. 1989. Biokonversi: Pemanfaatan Limbah Industri Pertanian. Pusat Antar Universitas Pangan dan Gizi.Institut Pertanian Bogor. Bogor

Hermawan. B., Lailatul Qodriyah, dan Candrarini Puspita. 2007. Sampah Organik sebagai Bahan Baku Biogas untuk Mengatasi Krisis Energi Dalam Negeri. Karya Tulis Ilmiah Mahasiswa. Universitas Lampung. Bandar Lampung. Diak-ses pada tanggal 30 September 2010 dari http://chemistry-addict-.word-press.com

http://eprints.unsri.ac.id/136/1/Pages_from_PROSIDING_AVOER_2011-30.pdf Di akses 22 Februari 2016

Mujahidah, Mappiratu ,Rismawaty S. 2013. Kajian Teknologi Produksi Biogas Dari Sampah Basah Rumah Tangga. Fakultas MIPA, Universitas Tadulako Online Jurnal of Natural Science, Vol. 2 (1): 25-34 ISSN: 2338-0950Maret 2013

Oemar G. R, dkk. 2007. Pengaruh Komposisi Feed terhadap Produksi Biogas dari Sampah Kota. Prosiding Seminar Nasional Fundamental dan Aplikasi Teknik Kimia 2007. Surabaya : Institut Teknologi Sepuluh November.

Pambudi, N. A., 2008. Pemanfaatan Biogas Sebagai Energi Alternatif. Universitas Sebelas Maret, Surakarta. http://www.dikti.org/?q = node/99 [25 Feb 2008].

Putro, S. 2007. Penerapan Instalasi Sederhana Pengolahan Kotoran Sapi Menjadi Energi Biogas Di Desa Sugihan Kecamatan Bendosari Di Kabupaten Sukoharjo.Warta. Vol: 10(2).

Ruddy Oktarino Zakaria, Mochammad Makmur, Mochammad Rozikin, 2014. Implementasi Program Sidoarjo Bersih Dan Hijau Yang Tertuang Dalam Surat KEPUTUSAN BUPATI NO 188 TENTANG TIM SIDOARJO BERSIH DAN HIJAU (Studi pada Dinas Kebersihan dan Pertamanan Kabupaten Sidoarjo) Jurusan Administrasi Publik, Fakultas Ilmu Administrasi Universitas Brawijaya, Malang Jurnal Administrasi Publik (JAP), Vol. 2, No.4, Hal. 666-672 
Schluter, A., T. Bekel., N.N. Diaz., M.Dondrup., R. Eichenlaub., K.H. Gartemann., I. Krahn., L. Krause., H. Kromeke., O. Krause., J.H. Mussgnug., H. Neuweger., K. Niehaus., A. Puhler., K.J. Runte., R. Szczepanowski., A. Tauch., A. Tilker., P. Viehover, \& A. Goesmann. (2008). Themetagenome of a biogas-producingmicrobial community ofaproduction-scale biogas plantfermenter analysed by the 454-pyrosequencing technology.Journalof Biotechnology.136: 77-90.

Sutrisno, Joko. 2010. Pembuatan Biogas dari Bahan Sampah Sayuran (Kubis, Kangkung, dan Bayam), Universitas PGRI Adibuana Surabaya Jurnal Teknik Waktu Volume 08 Nomor 01 Januari 2010 - ISSN: 1412 - 1867

Yunus, Muchammad. 1991. Pengelolahan Limbah Peternak. Universitas Brawijaya: Malang. --2015. Dialog Penanganan Sampah Plastik. http://www.menlh.go.id/rangkaian-hlh2015-dialog-penanganan-sampah-plastik/Di akses 22 Februari 2016 